\title{
Andrzej Zawistowski
}

Warszawa

\section{Kartki na wojnę, której nie było. Planowany mechanizm reglamentacji artykułów pierwszego zapotrzebowania w PRL w wypadku sytuacji nadzwyczajnej}

W gospodarce - co najpełniej przedstawiał Janos Korani — zauważyć można trzy sposoby alokacji dóbr i usług między gospodarstwa domowe: schemat ,aukcji” (czyli mechanizm rynkowy, w którym towar zostaje sprzedany za maksymalnie możliwą do uzyskania cenę), schemat „kolejki” (gdzie o ewentualnym zakupie decyduje właściwy moment i kolejność zgłoszenia się do punku sprzedaży) i schemat racjonowania (który z reguły jest wypadkową schematu wcześniejszego). Racjonowanie może być prowadzone przez dostawcę lub sprzedawcę (czyli żywiołowo) lub przez administrację (reglamentacja). Racjonowanie żywiołowe polegało na tym, że trafiający do sklepu towar sprzedawano czekającym na dostawę w ograniczonej ilości. O zasadach sprzedaży decydował personel sklepu (czasami według narzuconych przez zwierzchników zasad). Natomiast reglamentacja polegała na racjonowaniu za pomocą specjalnie dystrybuowanych wcześniej i ważnych czasowo dokumentów, które uprawniały do zakupu konkretnego towaru. Umożliwiało to także prowadzenie przez wprowadzającego reglamentację polityki polegającej na specjalnym traktowaniu wybranych grup społecznych, wiekowych, zawodowych i innych według przyjętego schematu.

Racjonowanie (spontaniczne i administracyjne) może odbywać się według różnych zasad: m.in. realizowane według kolejności potrzeb, sytuacji rodzinnej, zasług. Rzecz jasna bardzo często te schematy mogą przenikać się nawzajem. Generalnym celem jest redystrybucja dóbr na rzecz tych grup społecznych, które eliminują z rynku inne schematy alokacji ${ }^{1}$.

Wydany w 2000 r. Słownik wyrazów obcych tak definiował słowo „reglamentacja”: „regulowanie lub ograniczenie kupna, sprzedaży, produkcji pewnych artykułów zwykle z powodu ich niedoboru na rynku (fr. réglementation) ${ }^{2}$. Można śmiało stwierdzić, iż autor piszący tę definicję było obciążony pamięcią czasów Polski Ludowej. Przecież reglamentacja jest zjawiskiem w gospodarce rynkowej, które miało znacznie szerszy aspekt niż tylko przeciwdzia-

\footnotetext{
K. Hagemejer, Ekonomiczne i społeczne funkcje reglamentacji, w: Umowa o kartki, red. J. Kurczewski, Warszawa 2004, s. 39-42, 47; D. Jarosz, M. Pasztor, Afera mięsna: fakty i konteksty, Torun 2004, s. 146, 147.

${ }^{2}$ Stownik wyrazów obcych, Warszawa 2000, s. 948.
} 
łanie brakom rynkowym. Warto wspomnieć chociażby reglamentowanie obrotów z zagranicą (np. w okresie merkantylizmu) czy też jako element polityki gospodarczej mającej na celu rozwój rodzimej produkcji (przykład dziewiętnastowiecznego Królestwa Polskiego). W PRL reglamentacji podlegał np. obrót walutami i częściowo złotem.

Reglamentacja często utożsamiana jest przede wszystkim z zaopatrzeniem kartkowym. System ten polegał na wprowadzeniu systemu racjonowania artykułów pierwszej potrzeby (przede wszystkim żywności). Stosowany był w chwilach znacznej przewagi popytu nad podażą jako część systemu aprowizacyjnego ludności. Takie sytuacje z reguły były spowodowane wojnami, klęskami żywiołowymi, klęskami nieurodzaju. W tego rodzaju przypadkach w celu zapewnienia ludności możliwości zdobycia minimalnej ilości pożywienia, przeciwdziałania znacznemu wzrostowi cen oraz — co nie mniej ważne — zapewnienia spokoju społecznego władze decydowały się na określenie przysługujących ludności racji. Polegało to najczęściej na dystrybucji specjalnych kart zaopatrzenia (z informacją o przysługujących przydziałach) lub innych dokumentów upoważniających do zakupów (specjalnych zezwoleń, jednorazowych bonów, książeczek z miejscami na odnotowanie przydziału) ${ }^{3}$. Naturalne było, że system taki przygotowywano do zastosowania w razie pojawienia się sytuacji kryzysowej. Dobrym przykładem jest tu opracowanie systemu reglamentacji paliw w Stanach Zjednoczonych po pierwszym szoku naftowym (ostatecznie nie został on zastosowany).

Reglamentacja artykułów pierwszej potrzeby towarzyszyła Polakom w XX w. przez ponad trzecią część stulecia. Na ziemiach polskich kartki na artykuły codziennego użytku po raz pierwszy w pojawiły się w czasie Wielkiej Wojny (nazwanej wiele lat później pierwszą wojną światową). Wybuch konfliktu sprawił, że priorytetem gospodarek państwowych stało się zaopatrzenie walczącego wojska. Oznaczało to ograniczenie dostaw dla ludności cywilnej do niezbędnego minimum. Niemcy, którzy w latach 1914-1915 zajęli ziemie polskie znajdujące się dotychczas pod zaborem rosyjskim, szybko wprowadzili tam reglamentację żywności. Objęła ona przede wszystkim artykuły pierwszej potrzeby: chleb, mąkę, cukier i ziemniaki. Kartki były wówczas drukowane przez władze lokalne. W tym samym czasie także władze austriackie wprowadziły reglamentację żywności zarówno w Galicji, jak i na dawnych ziemiach polskich przed wojną należących Rosji, które pod okupacją austriacką nazwano Generalnym Gubernatorstwem Lubelskim.

Odzyskanie niepodległości w listopadzie 1918 r. nie umożliwiło zniesienia reglamentacji artykułów pierwszej potrzeby. Gospodarka wciąż była przede wszystkim nastawiona na potrzeby wojska, a w związku z tym ciągle obowiązywały ograniczenia w zaopatrywaniu się ludności. Jedyną zauważalną zmianą było to, że wydawane przez władze lokalne kartki stały się ważnym nośnikiem propaństwowej propagandy ${ }^{4}$. Reglamentację żywności zniesiono dopiero w 1921 r., po zakończeniu wojny z bolszewicką Rosją.

Po raz kolejny kartki pojawiły się w życiu Polaków podczas drugiej wojny światowej. Wprowadzona wówczas reglamentacja nie tylko limitowała i ograniczała możliwość zapatrywania się, ale przede wszystkim była elementem polityki dyskryminacji Polaków oraz

\footnotetext{
${ }^{3}$ W. Roszkowski, Kartkowe zaopatrzenie, w: Encyklopedia historii gospodarczej Polski do roku 1945, Warszawa1981, t. I, s. 301, 302.

${ }^{4}$ Emitowane wówczas kartki, podobnie jak wojenne, były bogato zdobione. Można na nich znaleźć portrety przywódców ówczesnej Rzeczypospolitej Polskiej — Józefa Piłsudskiego, Ignacego Paderewskiego, Józefa Hallera. Pojawiały się na nich ważne postacie historyczne, np. Józef Poniatowski, Tadeusz Kościuszko. Na kupony towarowe trafił także prezydent Stanów Zjednoczonych Thomas Woodrow Wilson, który na forum międzynarodowym upominał się o polską niepodległość. Na blankietach widniały symbole patriotyczne, herby polskich miast, wreszcie godło Polski.
} 
Żydów. Duże rozmiary przybrała ona zwłaszcza w Generalnym Gubernatorstwie. Przydziały kartkowe dla Niemców były wówczas czterokrotnie większe niż dla Polaków i aż dziewięciokrotnie większe od norm przewidzianych dla Żydów. Na kartki sprzedawano cukier, czarny chleb, mąkę, marmoladę, kawę zbożową, ziemniaki, tłuszcz i mięso. Ludność była w stanie przeżyć tylko dzięki mocno rozbudowanemu czarnemu rynkowi oraz własnej gospodarności.

Powojenny system reglamentacji Polacy odziedziczyli po okresie okupacji niemieckiej. System kartkowy niejako z marszu przejął Polski Komitet Wyzwolenia Narodowego, który starał się opanować sytuację na rynku zaopatrzenia ludności. Przez pierwsze tygodnie obowiązywało wręcz wiele wydanych przez okupanta kartek — zalegalizowanych jedynie polską pieczęcią.

PKWN zastosował wówczas tzw. system mieszany, tzn. ten sam towar dostępny był w sprzedaży reglamentowanej i wolnej. Było to rozwiązanie identyczne z funkcjonującymi wcześniej na ziemiach polskich i powszechnie wykorzystywane w wielu gospodarkach o charakterze rynkowym. Kartki stawały się w ten sposób swego rodzaju substytutem części wynagrodzenia, a były to sumy znaczne, np. w czerwcu 1945 r. chleb kartkowy kosztował od 0,75 do 1,5 zł, a „wolnorynkowy” 45-50 zł . W latach 1944-1948 r. na karki sprzedawano: chleb, mąkę, kaszę, ziemniaki, warzywa, ocet, naftę, zapałki, mięso, masło, tłuszcze, cukier, słodycze, mleko, kawę, herbatę, sól, opał, wyroby dziewiarskie. Przydziały uzależniono od wykonywanej pracy oraz miejsca zamieszkania uprawnionego.

Likwidacja tego etapu reglamentacji była rozłożona w czasie. Najwcześniej, bo w 1946 r., zrezygnowano z kartek na zapałki, a cały system oficjalnie zniesiono 1 I 1949 r. Były to $\mathrm{w}$ zasadzie działania fikcyjne (i propagandowo związane z powstaniem w grudniu $1948 \mathrm{r}$. PZPR), gdyż równolegle w niektórych miastach wprowadzono bony na tłuszcze i mleko. Zrezygnowano z nich dopiero na przełomie 1950 i $1951 \mathrm{r}$.

Jednak już w sierpnia $1951 \mathrm{r}$. zapadła decyzja o ponownym wprowadzeniu reglamentacji mięsa. Wówczas kartki przysługiwały zatrudnionym w 1363 zakładach pracy, położonych w czternastu województwach (na siedemnaście istniejących) oraz w dwóch miastach wydzielonych. Brak egalitaryzmu w podziale kartek wywołał wrogość w stosunku do osób je otrzymujących (np. pojawił się epitet „kacapskie folksdojcze” określający uprzywilejowanych). Zdarzały się przypadki demonstracyjnego niszczenia kartek lub żądania ich przyznania (nawet $\mathrm{z}$ przerywaniem pracy) ${ }^{6}$.

$\mathrm{Z}$ czasem rozszerzano listę reglamentowanych towarów - w grudniu $1951 \mathrm{r}$. dołączono masło i tłuszcze roślinne, w kwietniu 1952 r. mydło i środki piorące oraz cukier, w maju 1952 r. cukierki. Tak ograniczony zakres uprawnionych do zakupów reglamentowanych towarów spowodował jednak poważne napięcia społeczne, co doprowadziło w styczniu $1953 \mathrm{r}$. do rezygnacji z systemu kartkowego ${ }^{7}$.

Zniesienie reglamentacji w $1953 \mathrm{r}$. i podniesienie cen nie poszły w parze ze wzrostem poziomu zaopatrzenia sklepów. Przez kolejne lata władze komunistyczne wciąż borykały się z kłopotami w handlu wewnętrznym. Ekipa Władysława Gomułki wzbraniała się jednak przed wykorzystaniem reglamentacji jako sposobu redystrybucji dóbr. Maria Pasztor

\footnotetext{
5 Z. Grodek, Zaopatrzenie kartkowe w okresie Rządu Tymczasowego (31 grudnia 1944-czerwiec 1945), „Przegląd Historyczny” 1969, z. 4, s. 686, 687.

${ }^{6}$ M. Jastrząb, Puste pótki. Problem zaopatrzenia ludności w artykuły powszechnego użytku w Polsce w latach 1949-1956, Warszawa 2004, s. 160-167.

${ }^{7}$ Szerzej: A. Zawistowski, Trzy próby walki z nierównowaga w handlu detalicznym - trzy okresy reglamentacji artykułów pierwszej potrzeby w Polsce Ludowej, „Kwartalnik Kolegium EkonomicznoSpołecznego Studia i Prace" 2011, nr 3, s. 105-132.
} 
i Dariusz Jarosz przywołują ciekawą wypowiedź Stefana Jędrychowskiego, przewodniczącego Komisji Planowania przy Radzie Ministrów. 10 X 1959 r. odbyła się w Komitecie Centralnym Polskiej Zjednoczonej Partii Robotniczej narada z udziałem I sekretarzy komitetów wojewódzkich oraz sekretarzy ekonomicznych. Związana była z wprowadzaną właśnie podwyżką cen mięsa. Podczas dyskusji Jędrychowski odniósł się do pytania, czy lepszym rozwiązaniem braków rynkowych nie byłaby reglamentacja. Mówił: „System kartkowy to jest przedsięwzięcie typu wojennego albo zbliżonego do wojennego, $\mathrm{i}$ to $\mathrm{z}$ tego względu, jeżeli można tego uniknąć, to oczywiście lepiej w to nie wchodzić"».

Jędrychowski miał rację, jednak wojna nie była wówczas wcale odległą perspektywą. Sytuacja międzynarodowa wciąż nie była stabilna. Przełom lat pięćdziesiątych i sześćdziesiątych XX w. w stosunkach między ówczesnymi mocarstwami charakteryzował się ponownym wzrostem napięcia, choć na nieco innych zasadach niż w pierwszym okresie zimnej wojny. Było to widoczne w sowieckiej kampanii wzmacniania światowej pozycji komunizmu (prowadzonej zresztą pod zwodniczymi hasłami pokojowego współistnienia i rozbrojenia). Ofensywa sowiecka była prowadzona przede wszystkim na torach dyplomatycznych (np. wizyta Chruszczowa w USA w 1959 r.). W 1960 r. do ścisłego grona państw dysponujących arsenałem atomowym dołączyła Francja, w tym samym roku Sowieci zestrzelili nad swoim terytorium amerykański samolot szpiegowski. USA uporczywie próbowały pozbyć się Fidela Castro. Nawet wspomniane spotkanie w czerwcu 1961 r. Chruszczowa i Kennedy'ego nie doprowadziło do osłabienia napięcia. Symbolem zaostrzenia się sytuacji stała się rozpoczęta w nocy z 12 na 13 VIII 1961 r. budowa muru, izolującego Berlin Wschodni od enklawy demokratycznego świata — Berlina Zachodniego.

Czy sytuacja międzynarodowa miała wpływ na polskie przygotowania ekonomiczne do ewentualnego konfliktu? Prawdopodobnie tak, bo budowa muru dzielącego Berlin odbiła się w PRL ,tradycyjną" paniką sklepową9 i masowym wykupem towarów, m.in. alkoholu i cukru. Brak tego ostatniego powodował wówczas nawoływania do wprowadzenia reglamenta$\mathrm{cji}^{10}$. Jednak samą akcję przygotowywania systemu reglamentacji na wypadek sytuacji nadzwyczajnej rozpoczęto w PRL wcześniej. Otwarte pozostaje pytania, na ile przygotowania do „operacji berlińskiej” towarzyszy z NRD (zadecydowano o niej na początku sierpnia) były sygnałem alarmowym dla ich polskich kolegów. Na ile system zaaranżowano na wypadek zawirowań na rynku wewnętrznym, a na ile poważnie rozważano możliwość wybuchu konfliktu zbrojnego.

8 VIII 1961 r. podczas konferencji wicepremiera Piotra Jaroszewicza z przedstawicielami Komisji Planowania przy Radzie Ministrów, Wydziału Ekonomicznego KC PZPR, Ministerstwa Finansów, Ministerstwa Handlu Wewnętrznego oraz CSR „Samopomoc Chłopska" poinformowano, że Ministerstwo Handlu Wewnętrznego otrzymało zadanie, by w ciągu tygodnia przygotować wzór tzw. ślepych kartek, a po kolejnych siedmiu dniach przygotować pełny projekt systemu kartkowego ${ }^{11}$.

\footnotetext{
${ }^{8}$ D. Jarosz, Maria Pasztor, Afera mięsna, s. 245, 246.

9 Panika sklepowa polegała na masowym wykupowaniu towarów w obawie przed nadchodzącymi podwyżkami, wprowadzeniem (lub zniesieniem) reglamentacji czy w związku z zaostrzeniem się sytuacji międzynarodowej i ewentualną groźbą konfliktu zbrojnego. Por. D. Jarosz, M. Pasztor, Afera mięsna, s. 216, 217; K. Kosiński, Historia pijaństwa w czasach PRL. Polityka-obyczaje-szara strefapatologie, Warszawa 2008, s. 338..

${ }^{10}$ B. Brzostek, PRL na widelcu, Warszawa 2010, s. 55.

${ }^{11}$ Archiwum Akt Nowych (dalej: AAN), Urząd Rady Ministrów (dalej: URM) 123/6, Protokół z kon-
} 
Na kilka godzin przed rozpoczęciem blokady dróg wiodących z wschodniej części miasta do Berlina Zachodniego 12 VIII 1961 r. Komitet Ekonomiczny Rady Ministrów PRL podjął uchwałę dotyczącą organizacji reglamentacji w sytuacji kryzysowej. Uchwała dotyczyła zasad sprzedaży towarów w uspołecznionych przedsiębiorstwach handlu detalicznego w przepadkach nadmiernego wykupu artykułów codziennego użytku' ${ }^{12}$. Jeżeli w jej projekcie nie zaszły zmiany, to zgodnie z propozycją Ministerstwa Handlu Wewnętrznego zarówno ministerstwo, jak i wojewódzkie rady narodowe otrzymały możliwość wprowadzenia ilościowego ograniczenia sprzedaży artykułów codziennego zapotrzebowania (czyli czegoś na wzór reglamentacji spontanicznej). Uregulowanie dawało nie tylko prawo do wyznaczania ilości sprzedawanego towaru, ale także wprowadzania sankcji dla naruszających wprowadzone zasady ${ }^{13}$.

Najważniejszą częścią wspomnianej uchwały KERM była wydana także 12 VIII 1961 r. przez ministra handlu wewnętrznego Instrukcja nr $1 \mathrm{w}$ sprawie zasad sprzedaży towarów w uspołecznionych przedsiębiorstwach handlu detalicznego w przepadkach nadmiernego wykupu artykułów codziennego użytku ${ }^{14}$. W sposób szczegółowy podawała ona wytyczne, jak postępować w momentach „nadmiernego wykupu artykułów codziennego zapotrzebowania". W takiej sytuacji dozwolona została w sklepach jedynie sprzedaż w ilościach detalicznych. Zdefiniowano to jako ,[...] ilości towarów, które są zazwyczaj nabywane przez indywidualnego nabywcę przy normalnym, jednorazowym zakupie z uwzględnieniem zwiększonych zakupów w niektóre dni miesiąca, jak np. w dniu wypłat, w dniach targowych itp. W czasie spokoju na rynku [...] zasada sprzedaży w ilościach detalicznych powinna być stosowana $\mathrm{z}$ umiarem zapobiegającym formalistycznemu stosunkowi do uzasadnionych potrzeb uczciwych nabywców, aby przez nieuzasadnione i mechaniczne jej stosowanie nie wywołać paniki na rynku"15. Lista artykułów zagrożonych nadmiernym wykupem liczyła dwadzieścia trzy punkty ${ }^{16}$. Ważnym uzupełnieniem

ferencji odbytej w dniu 8 VIII 1961 r. pod przewodnictwem Wiceprezesa Rady Ministrów Piotra Jaroszewicza, k. 6.

${ }^{12}$ AAN, URM 218/51, Uchwała nr 312 KERM z dnia 12 VIII 1961 r. w sprawie zasad sprzedaży towarów $\mathrm{w}$ uspołecznionych przedsiębiorstwach handlu detalicznego $\mathrm{w}$ przepadkach nadmiernego wykupu artykułów codziennego użytku, k. 54; AAN, URM 62/27, Uchwała nr 312 KERM z dnia 12 VIII $1961 \mathrm{r}$. w sprawie zasad sprzedaży towarów w uspołecznionych przedsiębiorstwach handlu detalicznego w przepadkach nadmiernego wykupu artykułów codziennego użytku, k. 2.

${ }^{13}$ AAN, URM 124/8, Pismo Ministra Handlu Wewnętrznego do wiceprezesa Rady Ministrów PRL Piotra Jaroszewicza z 7 VIII 1961 r. Załącznik 1: Projekt Uchwały Komitetu Ekonomicznego Rady Ministrów, k. 1-3.

${ }^{14}$ AAN, URM 218/51, Instrukcja nr 1 Ministra Handlu Wewnętrznego z dnia 12 VIII 1961 r. w sprawie zasad sprzedaży towarów w uspołecznionych przedsiębiorstwach handlu detalicznego w przepadkach nadmiernego wykupu artykułów codziennego zapotrzebowania, k. 62-64; AAN, URM 62/27, Instrukcja nr 1 Ministra Handlu Wewnętrznego z dnia 12 VIII 1961 r. w sprawie zasad sprzedaży towarów w uspołecznionych przedsiębiorstwach handlu detalicznego w przepadkach nadmiernego wykupu artykułów codziennego zapotrzebowania, k. 3-7.

${ }^{15}$ AAN, URM 124/8, Pismo Ministra Handlu Wewnętrznego do wiceprezesa Rady Ministrów PRL Piotra Jaroszewicza z 7 VIII 1961 r. Załącznik 2: Wytyczne w zakresie sprzedaży w uspołecznionych przedsiębiorstwach towarów w przypadku nadmiernego wykupu artykułów codziennego zapotrzebowania, k. 5 .

${ }^{16}$ Mąka pszenna, makaron, kasze i płatki, ryż, mięso, wędliny, tłuszcz wieprzowy, wyroby wędliniarskie, margaryna i inne tłuszcze roślinne utwardzone, olej, ryby i przetwory rybne, sery twarde i twarogowe, jaja, cukier, spirytus i wódki, ocet, sól jadalna, zapałki, pieczywo, mydło, proszki 
wspomnianych wyżej operacji było ograniczenie możliwości zakupu towarów luksusowych na raty ${ }^{17}$.

18 VIII 1961 r. Komitet Ekonomiczny Rady Ministrów podjął uchwały w sprawie zmian w sprzedaży niektórych artykułów konsumpcyjnych ludności nierolniczej oraz sprzedaży niektórych artykułów w systemie bonowym ${ }^{18}$. Tego samego dnia minister handlu wewnętrznego wydał zarządzenie w sprawie ogólnych zasad sprzedaży towarów w związku z wprowadzeniem sprzedaży bonowej ${ }^{19}$. W ten sposób stworzono podstawy systemu, który w sytuacji kryzysowej miał zagwarantować minimalne zaopatrzenie obywateli PRL. Do rozstrzygnięcia pozostawał jedynie system dystrybucji kartek.

Zgodnie z decyzją wicepremiera Piotra Jaroszewicza w sierpniu i wrześniu 1961 r. Milicja Obywatelska przeprowadziła dwie operacje pod kryptonimami „Wicher” i „Niepogoda”. $\mathrm{W}$ ich ramach do wojewódzkich komend MO dostarczono dokumenty, a przede wszystkich karty zaopatrzenia, przygotowane do wydania stosownego sygnału. Dokumenty formalnie były depozytem Ministerstwa Handlu Wewnętrznego, zabezpieczone jego pieczęciami. Na całość zdeponowanego materiału składały się: pakiety oznaczone kryptonimem „Niepogoda”, koperty oznaczone kryptonimem ,Wicher” oraz worki oznaczone numerami i litera ,,a"20.

W momencie, w którym władze uznałyby, iż nastąpiła konieczność wykorzystania systemu reglamentacji, do miejsc deponowania dokumentów miano przekazać hasło „Wicher”. Wówczas koperta nim oznaczona powinna trafić do przewodniczącego prezydium wojewódzkiej rady narodowej ${ }^{21}$. Zawierała ona pismo (tajne spec. znaczenia) ministra handlu wewnętrznego z 26 VIII 1961 r. wraz z załączonymi kilkoma okazowymi bonami kategorii „P”, „R” $\mathrm{i}, \mathrm{E}^{\prime 22}$. Były to tzw. ślepe kartki — na bonach tych nie zaznaczono bowiem nazw towarów,

do prania, nafta. Mąka i ryż mogły być całkowicie wyłączę ze sprzedaży, gdyby zapotrzebowanie na nie wzrastało. AAN, URM 124/8, Pismo Ministra Handlu Wewnętrznego do Wiceprezesa Rady Ministrów PRL Piotra Jaroszewicza z 7 VIII 1961 r. Załącznik 2: Wytyczne w zakresie sprzedaży w uspołecznionych przedsiębiorstwach towarów w przypadku nadmiernego wykupu artykułów codziennego zapotrzebowania, k. 8; AAN, URM 123/6, Protokół z konferencji odbytej w dniu 8 VIII 1961 r. pod przewodnictwem Wiceprezesa Rady Ministrów Piotra Jaroszewicza, k. 4; AAN, URM 218/51, Instrukcja nr 1 Ministra Handlu Wewnętrznego z dnia 12 VIII 1961 r. w sprawie zasad sprzedaży towarów w uspołecznionych przedsiębiorstwach handlu detalicznego $\mathrm{w}$ przepadkach nadmiernego wykupu artykułów codziennego zapotrzebowania, k. 62-64.

${ }_{17}$ AAN, URM 123/6, Protokół z konferencji odbytej w dniu 8 VIII 1961 r., k. 6.

${ }_{18}$ Uchwata nr 009 KERM z 18 sierpnia $1961 \mathrm{r}$. w sprawie przejściowych zmian w sprzedaży niektórych artykułów konsumpcyjnych ludności nierolniczej; Uchwała $\mathrm{nr} 0010$ KERM z 18 sierpnia $1961 \mathrm{r}$. $w$ sprawie przygotowania do wprowadzenia sprzedaży niektórych artykułów systemem bonowym, w: A. Kochański, Informator historyczny, Warszawa 2000, t. II, s. 274.

${ }_{19}$ Zarzadzenie $\mathrm{nr} 4$ ministra handlu wewnętrznego z 18 sierpnia $1961 \mathrm{r}$. w sprawie ogólnych zasad sprzedaży towarów $w$ zwiąku z wprowadzeniem sprzedaży bonowej, w: A. Kochański, Informator historyczny, s. 274.

${ }^{20}$ Archiwum Instytutu Pamięci Narodowej (dalej: AIPN) 00133/203, Decyzja Ministrów Handlu Wewnętrznego i Usług oraz Spraw Wewnętrznych z dnia 24 VIII 1982 r. w sprawie trybu postępowania z zapasami bonów przewidzianych do stosowania w systemie reglamentacji zaopatrzenia ludności (,S” tajne egz. nr 1), k. 8.

${ }^{21}$ W latach 1950-1973 prezydia wojewódzkich rad narodowych stanowiły kolegialne organy zarządzające, w przybliżeniu odpowiadające funkcji wojewody.

${ }^{22}$ AIPN Bu 00133/203, Komenda Wojewódzka MO w Katowicach, Protokół z komisyjnego zniszczenia pakietów dokumentów i kopert, k. 13-15; ibidem, Komenda Wojewódzka MO w Kielcach, Protokół komisyjnego zniszczenia materiałów Ministerstwa Handlu Wewnętrznego Wydział Wojskowy, zdeponowanych w Komendzie Wojewódzkiej MO w Kielcach (11 X 1982 r.), k. 29-34. 
które miały być na ich podstawie sprzedawane (bądź wydawane), umieszczając jedynie literę odpowiadającą rodzajowi bonu oraz kolejny numer kuponu. Bon kategorii „P” składał się z czterdziestu kuponów, „R” — z trzydziestu, a „E” — z dziesięciu. Na każdym było miejsce na umieszczenie imienia i nazwiska właściciela, informacji o wydawcy oraz miejsce pieczę$\mathrm{ci}^{23}$. Taka konstrukcja kartki zapewne była podyktowana koniecznością bieżącego dostosowania reglamentacji do ewentualnych potrzeb. Z liczby przekazywanych kartek można wywnioskować, iż najbardziej popularny miał być bon „P”, następnie „R” i „E”. Dla przykładu: dla województwa lubelskiego ${ }^{24}$ przewidziano 416 tys. kartek „P”, 384 tys. „R”, 192 tys. „E”25.

$\mathrm{W}$ kopercie dostarczanej z powyższymi dokumentami były też po cztery egzemplarze niezbędnych dokumentów ogłaszających wprowadzenie reglamentacji. Znajdowały się więc tam: Zarządzenie nr 3 Ministra Handlu Wewnętrznego z 18 VIII 1961 r., zawierające decyzję o wprowadzeniu reglamentacji, Zarzadzenie $n r 4$ zawierające zasady wprowadzenia systemu sprzedaży bonowej, Instrukcja regulująca wprowadzanie bonów oraz „,pouczenia dla kierowników zakładów pracy oraz innych instytucji i organizacji uprawnionych do wydawania bonów”. Wszystkim dokumentom nadano gryf: „tajne spec. znaczenia”.

Pakiet „Niepogoda” miał być także dostarczony przewodniczącemu prezydium wojewódzkiej rady narodowej. Oprócz listu przewodniego znajdowały się w pakiecie: Uchwała nr 312 Komitetu Ekonomicznego Rady Ministrów z 12 VIII 1961 r., Instrukcja nr 1 Ministra Handlu Wewnętrznego z 12 VIII $1961 \mathrm{r}$. oraz załącznik do niej. Instrukcja zawierała zasady sprzedaży towarów w uspołecznionych przedsiębiorstwach handlu detalicznego w przypadku nadmiernego wykupu artykułów codziennego zapotrzebowania, a załącznik zawierał zestawienie artykułów żywnościowych. Najważniejsze były jednak wykazy artykułów i normy jednorazowej sprzedaży zgodne ze wspomnianą powyżej Instrukcją $n r 1^{26}$.

Ostatnią częścią depozytu były liczne worki. W workach oznaczonych literą „a” znajdowały się tysiące egzemplarzy zarządzeń nr 3, 4 oraz instrukcji i pouczeń. Inne, zaplombowane worki zawierały karty zaopatrzenia ${ }^{27}$. Oddzielny zasób stanowiły instrukcje KGMO z 16 i 26 VIII $1961 \mathrm{r}$. dotyczące postępowania z dostarczonymi pakietami.

Uzupełnieniem wprowadzonych regulacji było opracowanie w MON serii regulacji uzupełniających zasady funkcjonowania zaopatrzenia i skupu w warunkach nadzwyczajnych.

\footnotetext{
${ }^{23}$ Wzór talonów można zobaczyć w „bonusie” katalogu kartek z lat 1976-1989. J. Oleński, Ogólnopolskie kartki zaopatrzenia z lat 1976-1989, Warszawa 2010, s. 8, bonus. Autor nie identyfikuje tych kartek chronologicznie (stąd są one umieszczone w katalogu dotyczącym lat siedemdziesiątych i osiemdziesiątych XX w.) i tematycznie, odnotowując jedynie ich istnienie.

${ }^{24}$ Bon „P” najprawdopodobniej był przeznaczony dla wszystkich mieszkańców miast (w domyśle ludności pozarolniczej) — według stanu na koniec grudnia 1960 r. w lubelskich miastach mieszkało 457 tys. osób, z czego 377 tys. w miastach powyżej 10 tys. mieszkańców. Rocznik statystyczny 1974, Warszawa 1974, s. 67, 79.

${ }^{25}$ AIPN, IPN Bu 00133/203, Komenda Wojewódzka MO w Lublinie, Protokół zniszczenia pakietów oznaczonych kryptonimem „Niepogoda” i „Wicher” oraz dokumentów znajdujących się w workach oznaczonych obok kolejnego numeru litera ,a” (16 X 1982 r.), k. 41.

${ }^{26}$ Ibidem, Komenda Wojewódzka MO w Katowicach, Protokół z komisyjnego zniszczenia pakietów dokumentów i kopert, k. 13-15; ibidem, Komenda Wojewódzka MO w Kielcach, Protokół komisyjnego zniszczenia materiałów Ministerstwa Handlu Wewnętrznego Wydział Wojskowy, zdeponowanych w Komendzie Wojewódzkiej MO w Kielcach (11 X 1982 r.), k. 29-34.

${ }^{27}$ AIPN, IPN Bu 00133/203, Komenda Wojewódzka MO w Katowicach, Protokół z komisyjnego zniszczenia pakietów dokumentów i kopert, k. 13-15; IPN Bu 00133/203, Komenda Wojewódzka MO w Kielcach, Protokół komisyjnego zniszczenia materiałów Ministerstwa Handlu Wewnętrznego Wydział Wojskowy, zdeponowanych w Komendzie Wojewódzkiej MO w Kielcach, k. 29-34.
} 
Przygotowano regulacje dotyczące reglamentacji przerobu i obrotu niektórymi artykułami rolnymi i ich przetworami, wiązanej sprzedaży niektórych artykułów spożywczych i przemysłowych oraz warunków skupu i dostaw obowiązkowych ${ }^{28}$. Wspomniane wyżej depozyty trafiły do dziewiętnastu komend (zgodnie z ówczesnym podziałem administracyjnym siedemnaście województw + dwie komendy wydzielone w Krakowie i Warszawie) ${ }^{29}$.

Otwarte pozostaje pytanie, kiedy planowano użyć rozdystrybuowane kartki. Jest bardzo prawdopodobne, że myślano o tym już w sierpniu i wrześniu 1961 r. Informacje o sytuacji w handlu detalicznym zbierano wówczas bardzo starannie. 8 sierpnia nie zanotowano poważniejszych sytuacji kryzysowych. Jednak w kolejnych dniach nastąpił szturm na sklepy. W końcu miesiąca w Warszawie oraz województwach gdańskim, szczeciński i wrocławskim wprowadzono limitowanie sprzedaży soli, mąki, ryżu i kaszy (choć bez oficjalnego informowania klientów). Na obszarach wiejskich specyfiką wykupu było duże zainteresowanie naftą i zapałkami. Sytuację udało się opanować na początku października 1961 r., kiedy niepokój był zauważalny już tylko w województwie gdańskim i bydgoskim ${ }^{30}$.

Oczywiście wprowadzenie kartek miało być ostatecznością. „Na odprawie z kierownikami Wydziałów Handlu PWRN omówiono sposoby rozładowania objawów paniki, głównie drogą perswadowania kupującym niecelowości zwiększania zakupów ponad ilości detaliczne" ${ }^{\text {31 }}$. W cytowanym wcześniej komunikacie zawarto też informacje, że ,przygotowano ślepe kartki żywnościowe [...]. Worki z kartkami mają być otwarte na umówione hasło"32. Oznacza to, że cała operacja kartkowa została przygotowana $\mathrm{z}$ myślą o doraźnej sytuacji późnego lata 1961 r. Sytuacja jednak się unormowała i worki pozostały w magazynach. O depozycie ministerstwo jednak nie zapomniało, a 6 VI 1972 r. dokonano szczegółowej kontroli dokumentów ${ }^{33}$. Być może uznano, że stworzony mechanizm znakomicie nadaje się na wypadek ewentualnego konfliktu zbrojnego lub innych problemów. Został więc zachowany i zakonserwowany. O jego pełnej sprawności może świadczyć fakt, że w czasie paniki rynkowej wywołanej kryzysem kubańskim w 1962 r. nie podejmowano dodatkowych kroków w celu jego uaktualnienia czy modernizacji. Wówczas jednak też nie wprowadzono powszechnej reglamentacji.

Gdy w 1975 r. przeprowadzono w PRL reformę administracyjną, w ramach której powstało czterdzieści dziewięć województw, Ministerstwo Handlu Wewnętrznego i Usług rozpoczęło proces dyslokacji depozytów do nowych jednostek organizacyjnych MO. Tylko podporządkowanie sytemu aktualnemu podziałowi administracyjnemu miało sens w jego

\footnotetext{
${ }^{28}$ AAN, URM 137/38, Pismo Ministra Przemysłu Spożywczego i Skupu do Adama Wendla dyrektora Biura ds. Rad Narodowych URM, 17 XI 1961 r., k. 60.

${ }^{29}$ IPN Bu 00133/203, Notatka służbowa dotycząca dotychczasowej realizacji operacji „Niepogoda” i „Wicher” przygotowana przez naczelnika Wydziału I Biura Operacyjnego KGMO ppłk. J. Łucka, k. 5.

${ }^{30}$ AAN, URM 124/8, Notatka dyrektora Zarządu Obrotami Artykułami Spożywczymi w sprawie sytuacji na rynku w dniu 8 VIII br., k. 15 i n.; ibidem, Komunikat nr 1 Ministerstwa Handlu Wewnętrznego o sytuacji rynkowej z 30 VIII 1961 r., k. 22-25; ibidem, Komunikat nr 2 Ministerstwa Handlu Wewnętrznego o sytuacji rynkowej z 31 VIII 1961 r., k. 26-27; ibidem, Komunikat nr 4 Ministerstwa Handlu Wewnętrznego o sytuacji rynkowej z 9 IX 1961 r., k. 31; ibidem, Komunikat nr 16/61 Ministerstwa Handlu Wewnętrznego o sytuacji rynkowej z 13 X 1961 r., k. 37.

${ }^{31}$ Ibidem, Komunikat nr 1 Ministerstwa Handlu Wewnętrznego o sytuacji rynkowej z 30 VIII 1961 r., k. 24.

${ }^{32}$ Ibidem, k. 24.

${ }^{33}$ AIPN, IPN Bu 00133/203, Komenda Wojewódzka MO w Kielcach, Protokół komisyjnego zniszczenia materiałów Ministerstwa Handlu Wewnętrznego Wydział Wojskowy, zdeponowanych w Komendzie Wojewódzkiej MO w Kielcach, k. 29.
} 
wykorzystaniu. Operacja ta zakończyła się jednak fiaskiem, gdyż — jak raportowali milicjanci - ministerstwo nie było w stanie podać precyzyjnych danych demograficznych, umożliwiających odpowiedni podział kartek $^{34}$. Warto też pamiętać, że w ciągu niemal piętnastu lat zwiększyła się znacznie liczba mieszkańców Polski (z 29,8 mln w 1960 r. do 34,2 mln w 1975 r.) $)^{35}$. Jeszcze bardziej wzrosła liczba mieszkańców miast. Liczba kartek więc nie była adekwatna do potrzeb.

Dodatkowo depozyt stawał się dość kłopotliwy. Choć przeprowadzone wyrywkowo w 1976 r. kolejne kontrole nie wykazały braków, MO zaczęła sugerować, że lepszym miejscem składowania dokumentacji będą pomieszczenia będące w dyspozycji NBP. Ostatecznie sprawa nie została rozwiązana, a kartki pozostały w starych lokalizacjach ${ }^{36}$.

Przeprowadzano kolejne kontrole: pierwszą jeszcze 6 VI 1972 r., następnie (wspominaną powyżej) 24 VII 1976 r. oraz 26 III 1981 r. Dyrektor Biura Operacyjnego Komendy Głównej MO zawsze polecał dokonywanie dokładnego przeglądu przechowywanych dokumentów ${ }^{37}$.

Zastanawiające jest, dlaczego ze wspomnianego zapasu nie skorzystano latem 1976 r., gdy zamieszanie wywołane wprowadzaniem i odwoływaniem podwyżki cen spowodowało szturm na sklepy i wykup towarów, w tym tradycyjnie cukru ${ }^{38}$. Można jedynie próbować zrekonstruować przebieg zdarzeń. Kartki na cukier zostały wprowadzone 12 VIII 1976 r., jednak zamieszczoną na nich datą emisji jest 25 VII 1976 r. Jest to dokładnie dzień później niż wydane przez dyrektora Biura Operacyjnego KGMO polecenie dokonania przeglądu dokumentów dotyczących reglamentacji znajdujących się w depozycie milicyjnym ${ }^{39}$. Być może wówczas się okazało, że przygotowany piętnaście lat wcześniej system zupełnie nie jest adekwatny do

${ }^{34}$ IPN Bu 00133/203, Notatka służbowa dotycząca dotychczasowej realizacji operacji „Niepogoda” i „Wicher”, k. 5.

${ }^{35}$ Rocznik statystyczny 1980, Warszawa 1980, s. 29.

${ }^{36}$ IPN Bu 00133/203, Notatka służbowa dotycząca dotychczasowej realizacji operacji „Niepogoda” i „Wicher”, k. 5.

${ }^{37}$ AIPN, IPN Bu 00133/203, Komenda Wojewódzka MO w Kielcach, Protokół komisyjnego zniszczenia materiałów Ministerstwa Handlu Wewnętrznego, k. 29.

${ }^{38}$ O skali problemu niech świadczą cytaty z raportów, przytaczane przez Pawła Sasankę: „,7 lipca 1976 r. w Lublinie w sklepie przy ul. Okrzei kilkusetosobowy tłum złamał jednemu z kolejkowiczów nogę, a personel innego został obrzucony butelkami. W sklepie WSS nr 198 w Bydgoszczy thum liczący około 500 osób połamał ladę sklepową. 8 lipca w Rzeszowie, w sklepie obleganym przez kilkuset kupujących, wybito szyby, w związku z czym interweniowała milicja. W pięciu sklepach na terenie Trójmiasta w kolejkach wybierano komitety społeczne, czuwające nad sprzedażą całego dostarczonego do sklepu cukru. 9 lipca w sklepie WSS przy ul. Jadźwingów w Warszawie kilkusetosobowy thum wdarł się na zaplecze i - jak informowano w meldunku - «stosując groźbę zdemolowania pomieszczeń i pobicia personelu, zmusił do sprzedaży całotygodniowej normy cukru» [...] w Nowej Wsi w gminie Sępolno stojące w kolejce kobiety wdarły się do sklepu, z którego zabrały $20 \mathrm{~kg}$ cukru i rozdzieliły go między siebie, pozostawiając należność. W dwóch sklepach w województwie koszalińskim klienci przedarli się na zaplecze, aby upewnić się, czy rzeczywiście cukru nie ma. «Personel sklepów niejednokrotnie zwraca się do terenowych jednostek MO z prośbą o interwencję, gdyż oczekujący klienci okupują sklepy, grożąc ich zniszczeniem, wdzierając się na zaplecza sklepów. Mają miejsca pobicia sprzedawców (woj. skierniewickie, konińskie)» — głosił raport MSW”. Konwojenci i sprzedawcy starali się „uszczuplić” dostawy, sprzedając pozyskany cukier poza oficjalnym obrotem. Zdarzało się, że do sklepów — dzięki operatywności osób odpowiedzialnych za dostawę - zamiast cukru trafiała jedynie ekwiwalentna kwota pieniędzy. P. Sasanka, Czerwiec 1976. Geneza - przebieg — konsekwencje, Warszawa 2006, s. $376,382$.

${ }^{39}$ AIPN, IPN Bu 00133/203, Komenda Wojewódzka MO w Kielcach, Protokół komisyjnego zniszczenia materiałów Ministerstwa Handlu Wewnętrznego, k. 29. 
wprowadzonego rok wcześniej podziału administracyjnego kraju na czterdzieści dziewięć województw oraz liczby mieszkańców Polski. Przypomnę, że próba dyslokacji zapasu kartek, przygotowana przez Ministerstwo Handlu Wewnętrznego i Usług, zakończyła się fiaskiem. Dlatego decyzja o wprowadzeniu kartek na cukier przeciągnęła się i po prostu zdecydowano o druku nowych blankietów. W grę jednak mogą wchodzić także kwestie strategicznego bezpieczeństwa. Wykorzystanie depozytu w praktyce oznaczałoby konieczność budowy nowego systemu. Znacznie prościej było wydrukować nowe „bilety towarowe”, choć odwlekło to całą operację o trzy tygodnie ${ }^{40}$.

Wprowadzone w 1976 r. „bilety towarowe” na cukier przez ponad cztery lata były jedynymi, którymi posługiwali się na co dzień Polacy. Być może jednak zamieszanie z ich wprowadzeniem spowodowało, że postanowiono uwspółcześnić system reglamentacji „,wojennej”. Wciąż bowiem kryzysy na rynku zaopatrzenia wewnętrznego powodowały nawoływania do rozszerzenia istniejącej reglamentacji cukru także na inne artykuły ${ }^{41}$. Prace nad nowym systemem rozpoczęto w 1979 r. na polecenie sekretarza Komitetu Obrony Kraju. Przygotowano wówczas dokumenty mające wprowadzać reglamentację. W czerwcu 1979 r. do konsultacji trafiły projekty trzech zarządzeń Ministerstwa Handlu i Usług w sprawie: zasad i trybu sprzedaży w ramach reglamentacji, wprowadzenia reglamentacji na niektóre artykuły nieżywnościowe oraz ,zasad organizacji produkcji kulinarnej, jej sprzedaży i zaopatrywania zakładów gastronomicznych" ${ }^{42}$. Reglamentacja miała być wprowadzona na podstawie rozporządzenia Rady Ministrów. Do tego rodzaju sprzedaży przeznaczono artykuły żywnościowe ${ }^{43}$, mydło, proszek do prania oraz papierosy. Ich dostępność była zróżnicowana jedynie z uwzględnieniem podziału na ludność nierolniczą (różnicujące wielkość przydziałów bony ${ }^{44}$ „P”, „R”, ,E” i „Rd”45) i rolniczą (bony „W” przysługujące właścicielom gospodarstw powyżej 0,5 ha) ${ }^{46}$. Kupujący otrzymywał prawo jednorazowego zakupu miesięcznego przydziału towarów, z pominięciem mięsa i jego przetworów, mleka oraz pieczywa. Sprzedaż reglamentowana miała być prowadzona jedynie w wyznaczonych placówkach handlowych.

\footnotetext{
${ }^{40}$ AAN, URM 5.3/91, Zapis przebiegu obrad posiedzenia Rady Ministrów w dniu 12 VIII 1976 r., k. 263. Szerzej: A. Zawistowski, ,, To nie wstyd - bony, wstyd to kolejki”. Kartki na cukier 1976-1981 (w druku).

${ }^{41}$ A. Zawistowski, Wolanie o kartki. Reglamentacja jako pożądane przez spoteczeństwo rozwiąanie problemów z równowaga $w$ handlu wewnętrznym w latach 1976-1980, w: PRL na pochylni 1975-1980, Rzeszów 2016 (w druku).

${ }^{42}$ AIPN, IPN BU1098/6 t. 30, Pismo podsekretarza stanu w Ministerstwie Handlu Wewnętrznego i Usług Albina Kostrzewskiego do ministra spraw wewnętrznych Stanisława Kowalczyka z 25 VI 1979 r., k. 1-2.

${ }^{43}$ Pieczywo, ziemniaki, mąka pszenna, kasza, płatki, makarony, mięso i jego przetwory, thuszcze, cukier, sól oraz masło i mleko (tylko „E” i „Rd”). Co dziwne, wódka została zaliczona do produktów nieżywnościowych.

${ }^{44}$ Warto zauważyć, że nie używano obowiązującej wówczas w handlu nazwy „bilety towarowe”

${ }^{45}$ Dwa pierwsze były identyczne z wprowadzonymi w 1961 r., E miał 20 odcinków (zamiast 10). Bon „Rd” dotyczyć miał tylko mleka. Rolniczy bon „W” miał pozwalać na zakup pieczywa, soli, cukru, proszku do prania, mydła i papierosów.

${ }^{46}$ AIPN, IPN BU1098/6 t. 30, Projekt zarządzenia Ministra Handlu Wewnętrznego i Usług, załącznik do pisma podsekretarza stanu w Ministerstwie Handlu Wewnętrznego i Usług Albina Kostrzewskiego do ministra spraw wewnętrznych, k. 3-4; ibidem, Projekt instrukcji w sprawie reglamentowanej sprzedaży podstawowych artykułów żywnościowych oraz mydła, proszku do prania i papierosów na bony, załącznik do pisma podsekretarza stanu w Ministerstwie Handlu Wewnętrznego i Usług Albina Kostrzewskiego do ministra spraw wewnętrznych, k. 6-12.
} 
Prawidłowy bon musiał być częścią całego arkusza, być zaopatrzony w pieczęć organu wydającego. Pracownicy sklepów zostali zobowiązani do naklejania odciętych kuponów na arkusze po sto jednostek i kasowania ich pieczęciami sklepu i rozliczania co piętnaście dni ${ }^{47}$.

Bardziej skomplikowana miała być reglamentacja produktów nieżywnościowych. Ludność nierolnicza miała kupować na kartki różnego rodzaju tkaniny, okrycia i ubrania, bieliznę, pościel, wyroby dziewiarskie i pończosznicze, obuwie, rowery, wyroby z blachy ocynkowanej i emaliowanej, węgiel, brykiet, koks, drewno opałowe, szkło ciągnione, naftę, wódkę. Ludność rolnicza, oprócz wymienionych powyżej, miała otrzymać prawo do zakupu gwoździ, wyrobów hutniczych, narzędzi rolniczych i części zamiennych, tarcicy iglastej, cementu, wapna budowlanego, materiałów ściernych ${ }^{48}$, płyt azbestowo-betonowych, papy, pasz treściwych, nawozów sztucznych i - co dziwne - dodatkowych papierosów ${ }^{49}$. W odróżnieniu od artykułów żywnościowych miały być one dystrybuowane za pomocą specjalnych, wypełnianych przez uprawniony organ, talonów ze ściśle określonym przedziałem czasowym zakupów ${ }^{50}$. Pytaniem otwartym pozostaje, czy zestaw tych towarów związany był z wojskowymi kwestiami strategicznym, czy/i bieżącymi brakami towarowymi. Warto zauważyć, że w 1961 r. takiej listy towarów nie przygotowano, a jedynie wydrukowano uniwersalne „ślepe kartki”. Gdyby jednak spojrzeć na pochodzące z 1983 r. (choć z nieco innej sytuacji) zestawienie towarów, których brakuje na rynku, w dużej części listy się pokrywają ${ }^{51}$. Prawdopodobnie więc lista towarów przeznaczonych do reglamentacji miała swoje odbicie w bieżących brakach rynkowych. Także uwzględniając powyższe regulacje, przygotowano specjalne wytyczne dla zakładów publicznej gastronomii i innych punktów zbiorowego żywienia ${ }^{52}$.

Zapewne w związku z wprowadzeniem wspomnianych rozwiązań zaplanowano stopniową likwidację dotychczasowych zapasów kartek i druków w pierwszej połowie 1980 r. Do tego jednak nie doszło ${ }^{53}$. Zapewne wpływ miała na to sytuacja wewnętrzna PRL.

Lawinowe załamywanie się rynku, a następnie wydarzenia lata 1980 r. prawdopodobnie także zahamowały wprowadzenie w życie przepisów dotyczących reglamentacji wojennej. Związane było to również z tym, iż reglamentacja wkroczyła do życia Polaków w dużo więk-

\footnotetext{
${ }^{47}$ Ibidem, Projekt instrukcji w sprawie reglamentowanej sprzedaży podstawowych artykułów żywnościowych oraz mydła, proszku do prania i papierosów na bony, załącznik do pisma podsekretarza stanu w Ministerstwie Handlu Wewnętrznego i Usług Albina Kostrzewskiego do ministra spraw wewnętrznych, k. 6-12.

${ }^{48} \mathrm{~W}$ dokumencie błędnie ,ściennych”.

${ }^{49}$ Ibidem, Projekt zarządzenia Ministra Handlu Wewnętrznego i Usług w sprawie reglamentacji sprzedaży zaopatrzenia ludności w niektóre artykuły nieżywnościowe, załącznik do pisma podsekretarza stanu w Ministerstwie Handlu Wewnętrznego i Usług Albina Kostrzewskiego do ministra spraw wewnętrznych, k. 13-15.

${ }^{50}$ Ibidem, k. 16-19.

${ }^{51}$ Por.: Archiwum Główne Policji 748/28 t. 1, Urząd m.st. Warszawy, Wydział Handlu, Wykaz artykułów o niewystarczającej podaży w woj. stołecznym warszawskim, załącznik do Informacji o zasadach zaopatrywania odbiorców indywidualnych w artykuły spożywcze i przemysłowe w województwie stołecznym warszawskim, k. 132-134.

52 AIPN, IPN BU 1098/6 t. 30, Projekt zarządzenia Ministra Handlu Wewnętrznego i Usług w sprawie zasad produkcji kulinarnej, jej sprzedaży i zaopatrywania zakładów, załącznik do pisma podsekretarza stanu w Ministerstwie Handlu Wewnętrznego i Usług Albina Kostrzewskiego do ministra spraw wewnętrznych, k. 20-28.

${ }_{53}$ Por.: AIPN, IPN Bu 1098/7 t. 12, Informacja dyrektora Departamentu Wojskowego Ministerstwa Handlu Wewnętrznego i Usług Leonarda Łukaszuka z 22 III 1980 r., k. 1.
} 
szym niż wcześniej stopniu. W drugiej połowie 1980 r. pojawiły się reglamentacje o charakterze regionalnym, a w kwietniu 1981 r. do sprzedawanego na kartki cukru dołączyło mięso. Rozwiązało to reglamentacyjny wore ${ }^{54}$. Dopiero wraz z początkiem stycznia $1982 \mathrm{r}$. uregulowano dość chaotycznie wprowadzane wcześniej zasady reglamentacji artykułów pierwszej potrzeby. Nigdy jednak nie sięgnięto do zalegającego od lat depozytu. Jednocześnie wrócono natomiast do uwspółcześnienia tego rezerwowego systemu.

Równolegle z wprowadzeniem kartek na mięso w kwietniu 1981 r. zmieniono system reglamentacji „wojennej”. W depozytach pojawiły się wówczas dwie koperty: „A” — otwierana na hasło „Róża”, i „B” — na hasło „Wicher”, oraz pismo ministra handlu wewnętrznego i usług z 1 IV 1981 r. ${ }^{55}$ Nie znamy niestety ich zawartości, można jednak się domyślać, iż zaktualizowano dokumenty przygotowane w 1961 r. w myśl pomysłów z 1979 r.

Co charakterystyczne, do kwestii zapewnienia bezpieczeństwa w zaopatrzeniu w sytuacjach kryzysowych po raz kolejny wrócono w pierwszych tygodniach stanu wojennego. W styczniu 1982 r. Zygmunt Łakomiec, pierwszy zastępca ministra handlu i usług, pisał do komendanta głównego MO gen. Józefa Beima: „W ramach przygotowań obronnych na czas wojny zostały wydrukowane dla celów reglamentacji zaopatrzenia ludności i zmagazynowane w Warszawie odpowiednie ilości kart zaopatrzenia, które powinny być rozwiezione do wszystkich województw i tam przechowywane we właściwie przygotowywanych i chronionych pomieszczeniach. Ze względu na to, że siedziby komend wojewódzkich Milicji Obywatelskiej dają największą gwarancję skutecznej ochrony kart zaopatrzenia przed kradzieżą i zniszczeniem, proszę uprzejmie Obywatela Generała o przyjęcie propozycji zmagazynowania kart zaopatrzenia $w$ tych komendach i wydania polecenia przygotowania odpowiednich pomieszczeń" ${ }^{6}$. MO wykorzystało jednak po raz kolejny argumenty z lat siedemdziesiątych i zaproponowało, by kartki trafiły do urzędów wojewódzkich lub wojewódzkich sztabów wojskowych ${ }^{57}$.

Rzeczywiście tak się stało ${ }^{58}$. W marcu 1982 r. na polecenie Ministerstwa Handlu Wewnętrznego i Usług do urzędów wojewódzkich trafiły blankiety kartek używanych w ,w pierwszym okresie wojny". Były to kartki dwojakiego rodzaju. Na papierze z różowym giloszem wydrukowano kartki, które miały trafić do rolników, których jedynym źródłem utrzymania były gospodarstwa rolne powyżej 0,5 ha, oraz dla ich rodzin. Kartki z żółtym giloszem zostały przeznaczone dla pozostałej ludności ${ }^{59}$. Każda z kartek (oznaczonych w.z. — prawdopo-

\footnotetext{
${ }^{54}$ Warto przypomnieć, że kolejny przegląd kartkowej dokumentacji odbył się w momencie rozwiązywania się „kartkowego worka” w końcu marca 1981 r. Kilka dni później uwspółcześniono „wojenny system".

${ }_{55}$ Archiwum Państwowe w Szczecinie (dalej: APSz), Urząd Wojewódzki w Szczecinie XXV/96, Pismo Lucjana Jaskólskiego, podsekretarza stanu w Ministerstwie Handlu Wewnętrznego i Usług, do wojewody szczecińskiego Tadeusza Waluszkiewicza z dnia 6 II 1982 r., k. 10.

56 AIPN, IPN Bu 00133/203, Pismo pierwszego zastępcy ministra handlu i usług Zygmunta Łakomca do komendanta głównego MO gen. Józefa Beima z 19 I 1982 r., k. 2.

${ }^{57}$ Ibidem, Notatka służbowa dotycząca dotychczasowej realizacji operacji „Niepogoda” i „Wicher”, k. 5.

${ }^{58}$ APSz, Urząd Wojewódzki w Szczecinie XXV/24, Pismo I zastępcy ministra handlu wewnętrznego i usług Zygmunta Łakomca do wojewody szczecińskiego Stanisława Malca z dnia 5 VI 1982 r., k. 5.

${ }_{59}$ Ibidem, Pismo dyrektora Departamentu Spraw Obronnych Ministerstwa Handlu Wewnętrznego

i Usług Tadeusza Antoniuka do dyrektora Wydziału Handlu i Usług Urzędu Wojewódzkiego w Szczecinie z dnia 17 III 1982 r., k. 8.
} 
dobnie wkładka zaopatrzenia ${ }^{60}$ ) zawierała trzydzieści jeden kuponów oznaczonych cyframi arabskimi, trzy kupony rezerwy oraz kupon rejestracyjny. Na środku pozostawiono miejsce na numer, nazwisko oraz adres posiadacza. Kartka nie miała żadnych danych uszczegółowiających rodzaje dystrybuowanych towarów.

Dostarczenie nowych kart zaopatrzenia spowodowało dość duży zamęt. Równolegle zaczęły funkcjonować dwa systemy: utworzony w 1961 r. i zreformowany dwadzieścia lat później oraz nowy, wprowadzony w marcu 1982 r. Konieczne więc było unormowanie sytuacji. W sierpniu 1982 r. minister handlu wewnętrznego i usług wydał zarządzenie nr 2 uchylające niektóre akty prawne regulujące system reglamentacji zaopatrzenia na wypadek czasu „W”. W nawiązaniu do tej decyzji ministrowie spraw wewnętrznych oraz handlu i usług wydali decyzję nakazującą komendom wojewódzkim zniszczenie pakietów i kopert przygotowanych na wypadek wojny. Worki zawierające karty zaopatrzenia trafiły do organów administracji wojewódzkiej (według podziału sprzed 1975 r.) ${ }^{61}$. Co ciekawe — zapasy bonów przekazanych do urzędów wojewódzkich mogły być wykorzystywane w razie konieczności w istniejącym wówczas systemie reglamentacji na podstawie decyzji Ministerstwa Handlu Wewnętrznego i Usług (także na wniosek administracji państwowej stopnia wojewódzkiego ${ }^{62} .15$ XII 1982 r. dyrektor Biura Operacyjnego MO płk Stanisław Jałoszyński zameldował o zakończeniu akcji niszczenia pozostałych materiałów ${ }^{63} .8$ IV 1983 r. Komitet Obrony Kraju przyjął uchwałę uchylającą uchwały KERM nr 312 z 12 VIII 1961 r. oraz uchwały nr 009 i 0010 KERM z 18 VIII 1961 r. ${ }^{64}$ Argumentem za ich uchyleniem było to, iż przedmiotowe kwestie zostały uregulowane w dekrecie z 12 XII 1981 r. o stanie wojennym ${ }^{65}$.

Worki z kartkami „wojennymi” przez następne lata zalegały w pomieszczeniach urzędów wojewódzkich. W styczniu 1988 r. minister handlu i rynku wewnętrznego zarządził zniszczenie zapasów bonów „P”, „R” i „E”66. Kartki „żółte” i „,różowe” pozostały w ma-

\footnotetext{
${ }^{60}$ Oznaczenie „w.z.” pojawiło się na karkach, które wprowadzano do obiegu od lipca 1981 r., używano go do końca $1983 \mathrm{r}$.
}

${ }_{61}$ AIPN, IPN Bu 00133/203, Decyzja Ministrów Handlu Wewnętrznego i Usług oraz Spraw Wewnętrznych z dnia 24 VIII 1982 r. w sprawie trybu postępowania z zapasami bonów przewidzianych do stosowania w systemie reglamentacji zaopatrzenia ludności („,S” tajne egz. nr 1), k. 8; APSz, Urząd Wojewódzki w Szczecinie XXV/96, Pismo Lucjana Jaskólskiego, podsekretarza stanu w Ministerstwie Handlu Wewnętrznego i Usług, do wojewody szczecińskiego Tadeusza Waluszkiewicza, k. 10; APSz, Urząd Wojewódzki w Szczecinie XXV/24, Pismo I zastępcy ministra Handlu Wewnętrznego i Usług Zygmunta Łakomca do wojewody szczecińskiego Stanisława Malca, k. 5.

${ }^{62}$ AIPN Bu 00133/203, Decyzja Ministrów Handlu Wewnętrznego i Usług oraz Spraw Wewnętrznych z dnia 24 VIII 1982 r. w sprawie trybu postępowania z zapasami bonów przewidzianych do stosowania w systemie reglamentacji zaopatrzenia ludności, k. 10.

${ }^{63}$ Ibidem, Informacja dyrektora Biura Operacyjnego KGMO Stanisława Jałoszyńskiego dla dyrektora Departamentu Spraw Obronnych Ministerstwoa Handlu Wewnętrznego i Usług z 15 XII 1982 r., k. 81. ${ }^{64}$ Uchwała nr 3/83 Komitetu Obrony Kraju z dnia 8 IV 1983 r. w sprawie uchylenia mocy obowiązującej niektórych uchwał Komitetu Obrony Kraju i Komitetu Ekonomicznego Rady Ministrów oraz prowadzenia dalszych prac związanych z przygotowywaniem administracji państwowej i gospodarki narodowej na czas obowiązywania stanu wojennego ze względu na obronność państwa, „Biuletyn Komitetu Obrony Kraju" 1983, nr 39-A, poz. 189.

${ }^{65}$ Artykuł 31 Dekretu z dnia 12 grudnia 1981 r. o stanie wojennym, Dziennik Ustaw PRL 1981, nr 29, poz. 154. W rzeczywistości (choć tylko formalnie) tego dnia przyjęto dwa niekorespondujące ze sobą akty prawne dotyczące reglamentacji.

${ }^{66}$ APSZ, Urząd Wojewódzki w Szczecinie XXV/96, Zarządzenie nr 1 dyrektora Wydziału Handlu Urzędu Wojewódzkiego w Szczecinie z dnia 20 VI 1988 r., k. 1. 
gazynach. W XXI w. w kolejnych latach były sukcesywnie niszczone, jako ostatni dokonał tego Pomorski Urząd Wojewódzki w Gdańsku w 2009 r. Nie oznacza to, że zlikwidowano wówczas regulacje „wojenne”. Raczej po raz kolejny je zmieniono, a nowy system wciąż oczywiście niejawnie - nadal obowiązuje.

Problem reglamentacji w sytuacjach nadzwyczajnych jest w polskim prawodawstwie wciąż obecny. W ustawie o stanie klęski żywiołowej przewidziano możliwość „całkowitej lub częściowej reglamentacji zaopatrzenia w określonego rodzaju artykuły" ${ }^{67}$. Z kolei w ustawach o stanie wyjątkowym i stanie wojennym jako pierwsze z możliwych ograniczeń wolności i praw człowieka i obywatela uznano „,dostęp do towarów konsumpcyjnych, poprzez całkowitą lub częściową reglamentację zaopatrzenia ludności”. Dla osób naruszających zasady reglamentacji zaopatrzenia ludności przewidziano karę aresztu lub grzywny ${ }^{68}$. Pośrednio poprzez możliwość ustalania przez Radę Ministrów za pomocą rozporządzenia wysokości cen urzędowych i wysokości urzędowych marż handlowych — ewentualność reglamentacji daje też ustawa o cenach. Zarezerwowane jest to jednak dla przypadków ,szczególnych zagrożeń dla właściwego funkcjonowania gospodarki państwa"69.

Zorganizowany w $1961 \mathrm{r}$. system reglamentacji w sytuacji nadzwyczajnej nigdy nie został zastosowany w praktyce. Oczywiście PRL nie znalazła się w sytuacji wojny (nie wliczając w to stanu wojennego), jednak warunki określane jako „nadzwyczajne” w zakresie zaopatrzenia ludności w podstawowe artykuły konsumpcyjne zdarzały się wielokrotnie (a w latach 1976-1989 były wręcz stałe). Dlaczego więc nie skorzystano z istniejących zapasów druków i opracowanego systemu? Powody mogą być co najmniej dwa: obawa przed utratą systemu „militarnego” i konieczność jego powtórnego przygotowania oraz (a może przede wszystkim) jego kompletna niesprawność po reformie administracyjnej z 1975 r. i wzrost liczby obywateli. O tym, że system miał jednak nadal istnieć, świadczą podjęte w drugiej połowie lat siedemdziesiątych i po 1981 r. próby jego przebudowy. Gdy został naprawiony i dostosowany do nowego podziału administracyjnego - reglamentacja w Polsce funkcjonowała już pełną mocą. Co więcej — stopień skomplikowania kartkowego życia Polaków w pierwszej połowie lat osiemdziesiątych był wielokrotnie większy niż ten zakładany przez wojskowych. Pozostawiano go jednak jako jeden z elementów przeciwdziałania „sytuacji kryzysowej”. Kartki wyprodukowane na potrzeby systemu „wojennego” pozostały w piwnicznych magazynach.

Słowa kluczowe: reglamentacja, PRL, gospodarka niedoboru, kartki

\section{Bibliografia}

Brzostek B., PRL na widelcu, Warszawa 2010, s. 55.

Grodek Z., Zaopatrzenie kartkowe w okresie Rządu Tymczasowego (31 grudnia 1944-czerwiec 1945), „Przegląd Historyczny” 1969, z. 4, s. 686, 687.

\footnotetext{
${ }^{67}$ Ustawa z dnia 18 kwietnia 2002 r. o stanie klęski żywiołowej, Dziennik Ustaw RP 2002, nr 62, poz. 558.

${ }^{68}$ Ustawa z dnia 21 czerwca 2002 r. o stanie wyjątkowym, Dziennik Ustaw RP 2002, nr 113, poz. 985; Ustawa z dnia 29 sierpnia 2002 r. o stanie wojennym oraz o kompetencjach Naczelnego Dowódcy Sit Zbrojnych i zasadach jego podległości konstytucyjnym organom Rzeczypospolitej Polskiej, Dziennik Ustaw RP 2002, nr 156, poz. 1301.

${ }^{69}$ Ustawa z dnia 5 lipca 2001 r. o cenach, Dziennik Ustaw RP 2001, nr 97, poz. 1050 z późniejszymi zmianami.
} 
Hagemejer K., Ekonomiczne i społeczne funkcje reglamentacji, w: Umowa o kartki, red. J. Kurczewski, Warszawa 2004, s. 51.

Jastrząb M., Puste pótki. Problem zaopatrzenia ludności w artykuły powszechnego użytku w Polsce w latach 1949-1956, Warszawa 2004, s. 160-167.

Kochański A., Informator historyczny, Warszawa 2000, t. II, s. 274.

Kosiński K., Historia pijaństwa w czasach PRL. Polityka-obyczaje-szara strefa-patologie, Warszawa 2008, s. 342, 542.

Oleński J., Ogólnopolskie kartki zaopatrzenia z lat 1976-1989, Warszawa 2010, s. 18-37.

Roszkowski W., Kartkowe zaopatrzenie, w: Encyklopedia historii gospodarczej Polski do roku 1945, Warszawa1981, t. I, s. 301, 302.

Sasanka P., Czerwiec 1976. Geneza - przebieg - konsekwencje, Warszawa 2006.

Stownik wyrazów obcych, Warszawa 2000, s. 948.

Zawistowski A., Trzy próby walki z nierównowaga $w$ handlu detalicznym - trzy okresy reglamentacji artykułów pierwszej potrzeby w Polsce Ludowej, „Kwartalnik Kolegium Ekonomiczno-Społecznego Studia i Prace" 2011, nr 3, s. 105-132.

Zawistowski A., Wołanie o kartki. Reglamentacja jako pożądane przez spoleczeństwo rozwiąanie problemów z równowaga w handlu wewnętrznym w latach 1976-1980, w: PRL na pochylni 1975-1980, Rzeszów 2016 (w druku).

\section{Ration Cards for a War that Never Came. Planned Mechanism of Rationing Basics in the People's Republic of Poland in the Case of an Extraordinary Situation}

Twentieth-century Poland experienced four periods of rationing basics: 1915-1921 (i.e. the First World War and the Polish-Bolshevik war), 1939-1949 (World War II and the post-war period), 1951-1953 (the height of Stalinism), and 1976-1989 (the breakdown of the communist economy and years of a universal lack of commodities in shops). Against this background the fact that during the 1961 Berlin Crisis the authorities of the People's Republic of Poland made preparations for rationing in case of an extraordinary situation remains totally unknown. The system in question was based upon the structures of the Civic Militia, but was never applied, even when conditions prevailing on the domestic market required rapid intervention and the introduction of rationing (e.g. in 1976). The article presents the system in question as well as its structure, organisation, and evolution. The author tried to solve the question why this carefully planned system and millions of printed ration cards were destroyed and never used. 